\title{
The epidemiology of bacterial pneumonia in Black Bengal goats in Bangladesh
}

\author{
MA Momin, MA Islam*, MM Khatun, MM Rahman and MA Islam \\ Department of Microbiology and Hygiene, Faculty of Veterinary Science, Bangladesh \\ Agricultural University, Mymensingh-2202, Bangladesh
}

\begin{abstract}
Goat pneumonia is commonly caused by infectious agents. The present study was conducted at Mymensingh Sadar (District headquarters) and Ullahpara Upazillas (Subdistrict). In each area goats with a history of pneumonia were identified. Age, sex, season, health status and hygienic practices of the affected flocks were recorded. Lungs and nasal swabs were collected from 250 Black Bengal goats for bacteriological examination. The prevalence of pneumonia was higher in young goats (1-12 months old) than in adults (>12 to 36 months old) $(33 \%$ and $11.3 \%$, respectively) $(\mathrm{P}<0.05)$. The prevalence in female goats was higher than in male goats $(23.0 \%$ and $12.0 \%$, respectively). In winter prevalence was higher $(27.1 \%)$ than in summer $(11.0 \%)(\mathrm{P}<0.05)$. (Bangl. vet. 2014. Vol. 31, No. 2, 70 - 73)
\end{abstract}

\section{Introduction}

Pneumonia in goat is characterized by fever $\left(40-41^{\circ} \mathrm{C}\right)$, anorexia, painful coughing, dyspnoea, mucopurulent nasal discharge and depression. It is one of the most common respiratory illnesses in goats throughout the world (Ackermann and Brogden, 2000). Although, pneumonia occurs more frequently in kids, it also affects adults. Pasteurella multocida and Pasteurella haemolytica are associated with outbreaks of acute pneumonia and death of goats of all ages (Falade, 2002). These bacteria are commonly found in the upper respiratory tract of healthy goats. Poor management, transportation stress, overcrowding, sudden changes of temperature and humidity, poor housing; viral infection (e.g. parainfluenza-3 virus), lung parasites (Dictyocaulus) and stress predispose goats to pneumonia. Pneumonia can lead to widespread financial loss because of death, reduced live weight, delayed marketing, treatment cost and unthriftiness (Davies et al., 1997; Daniel et al., 2006). Pneumonia of goats is reported in Bangladesh (Momin et al., 2011). P. multocida and Staphylococcus aureus have been associated with pneumonia in Black Bengal goats (Momin et al., 2011). In order to control pneumonia in goats, risk factors should be determined.

\section{Materials and Methods}

\section{Study areas}

This study was conducted at Mymensingh Sadar (District headquarters) and Ullahpara Upazilla (Sub-district), Sirajgonj in Bangladesh from May 2009 to April 2010.

\footnotetext{
*Corresponding author:- E-mail: islamma@bau.edu.bd
} 


\section{Goats}

Goats $(n=250)$ manifesting the characteristic clinical signs of respiratory distress such as: high fever $\left(40-41^{\circ} \mathrm{C}\right)$, anorexia, dyspnoea, coughing and depression were selected. In Mymensingh Sadar, the study area included the Veterinary Teaching Hospital, Bangladesh Agricultural University (BAU), BAU goat farm, Bulbul private goat farm and Kamal-Ranjit (KR) shopping centre. In Ullahpara of Sirajganj district, the study was conducted at Howrah village.

\section{Collection of samples}

Nasal swabs were collected from clinically sick goats $(n=247)$ using sterile cotton bud. Lung swabs from three dead goats were collected from the inner core of the lung using sterile cotton buds during necropsy. Swab samples were placed immediately into the Falcon tubes containing $10 \mathrm{~mL}$ nutrient broth. All swab samples were transported to the laboratory using ice box and kept at $4^{\circ} \mathrm{C}$ until use. Age, sex, health status and husbandry practice were recorded (Table 1) by the animals' attendants using a pretested questionnaire.

Table 1. History of goats used in the study

\begin{tabular}{ll|c}
\hline \multicolumn{1}{c|}{ Variables } & \multicolumn{1}{c}{ Category level } & Number of observation \\
\hline Age & $1-12$ months & 100 \\
Sex & $>12-36$ months & 150 \\
\multirow{3}{*}{ Seasons } & Male & 67 \\
\multirow{2}{*}{ Health status } & Female & 183 \\
\multirow{3}{*}{ Condition of rearing } & Winter (November to February) & 140 \\
& Summer (March to May) & 110 \\
& Poor & 190 \\
& Good & 60 \\
& Unsatisfactory & 175 \\
& Satisfactory & 75 \\
\hline
\end{tabular}

\section{Bacteriological study}

Nasal and lung swab samples were inoculated onto nutrient agar and blood agar, Eosin Methylene Blue (EMB) agar and MacConkey agar media and incubated at $37^{\circ} \mathrm{C}$ for 24 hours. The colonies on primary culture were repeatedly sub-cultured by streak plate method until pure cultures with homogenous colonies were obtained (Cheesbrough, 1985). Identification of bacteria was performed by colony morphology, Gram's stain and biochemical tests (Cheesbrough, 1985).

\section{Statistical analysis}

Statistical analysis was performed using 'Statistical package for the social sciences' (SPSS), version 17.0 (UK). The association between each risk factor and the outcome 
variable was assessed using the Chi-square $\left(X^{2}\right)$ test. For all analysis a $p$ value of $\leq 0.05$ was considered to be statistically significant.

\section{Results and Discussion}

The results are shown in Table 2. Prevalence of pneumonia is based on the bacteriological findings. When Pasteurella multocida and Staphylococcus aureus were isolated from nasal swabs or lung tissue, this was considered as evidence of pneumonia (Momin et al., 2011; Oros et al., 1997). Nutrition, immune status, climate and housing might influence the occurrence of goat pneumonia caused by bacterial pathogens (Pinheiro et al., 2000; Kumar et al., 2004).

Table 2. Prevalence of pneumonia in Black Bengal goats on the basis of clinical signs

\begin{tabular}{l|l|c|c}
\hline $\begin{array}{c}\text { Epidemiological } \\
\text { parameters }\end{array}$ & \multicolumn{1}{c|}{ Level } & $\begin{array}{c}\text { No. of animal } \\
\text { examined }\end{array}$ & $\begin{array}{c}\text { No. of animals affected and } \\
\text { prevalence }(\%)\end{array}$ \\
\hline Age & $1-12$ months & 100 & $33(33.0)$ \\
Sex & $12-36$ months & 150 & $17(11.3)$ \\
Season & Male & 67 & $8(11.9)$ \\
\multirow{5}{*}{ Health Status } & Female & 183 & $42(23.0)$ \\
\multirow{3}{*}{ Condition of rearing } & Winter & 140 & $38(27.1)$ \\
& Summer & 110 & $12(10.9)$ \\
& Poor & 190 & $43(22.6)$ \\
& Good & 60 & $7(11.7)$ \\
& Unsatisfactory & 175 & $39(24.4)$ \\
& Satisfactory & 75 & $11(12.2)$ \\
\hline
\end{tabular}

In this study the overall prevalence of pneumonia was 20\% (50 of 250). A study conducted in Nigeria recorded only $0.1 \%$ prevalence of pneumonia in goats (Adamu and Ameh, 2007). This study recorded higher prevalence of pneumonia in goats of 112 months of age (33\%) as compared to goats of $>12$ to 36 months of age (11.3\%): the difference is statistically significant $(\mathrm{P}<0.05)$. Kumar et al. (2004) recorded a higher incidence of pneumonia in $3-6$ month-old goats $(25.5 \%)$ as compared to $>12$ months age goats $(3.3 \%)$ in India. Young animals are more prone to develop pneumonia caused by bacterial agents; however, adult animals are also susceptible, particularly when immuno-compromised (Rimoldi and Moeller, 2013).

Prevalence was higher in female goats $(23.0 \%)$ than male $(11.9 \%)$. In the winter prevalence was higher than in summer $(27.1 \%$ and $10.9 \%$, respectively) the difference is statistically significant $(\mathrm{P}<0.05)$. Temperature fluctuation in the winter and summer appeared to be the major determinant of pneumonia in goats (Kumar et al., 2004). A study conducted in India on Barbari goats recorded higher prevalence of pneumonia in the winter (39.4\%) than in summer (33.8\%) (Kumar et al., 2004). 
Goats in poor health showed higher pneumonia prevalence than goats in good health $(22.6 \%$ and $11.7 \%$, respectively). Goats reared under unsatisfactory hygienic conditions exhibited higher prevalence of pneumonia than goats reared under satisfactory hygienic conditions $(24.4 \%$ and $12.2 \%$, respectively). Poor husbandry is a predisposing factor to pneumonia in goats (Tariq, 1980).

Results of this study suggest that bacterial pneumonia is endemic in the study areas and underscore the need for prevention and control measures.

\section{References}

Ackermann MR, Brogden KA 2000: Response of the ruminant respiratory tract to Mannheimia (Pasteurella haemolytica). Microbes and Infection 2 1079-1088.

Adamu JY, Ameh JA 2007: Prevalence of pneumonia among slaughtered cattle, goats and sheep in Maiduguri abattoir, Maiduguri, Nigeria. Sahel Journal of Veterinary Science 6 5-8.

Cheesbrough M 1985: Medical laboratory manual for tropical countries. 11 Microbiology. pp. $400-480$.

Daniel JA, Held JE, Brake DG, Wulf DM, Epperson WB 2006: Evaluation of the prevalence and onset of lung lesions and their impact on growth of lambs. American Journal of Veterinary Research 67 890-894.

Davies RL, Arkinsaw S, Selander RK 1997: Evolutionary genetics of Pasteurella hemolytica isolates recovered from cattle and sheep. Infection and Immunity 65 3585-3593.

Falade S 2002: Further Pasteurella isolates from the republic of Zambia. Tropical Veterinarian 20 130-131.

Kumar A, Gupta V, Rana R, Vaid RK, Vihan VS, Barua S 2004: Incidence of caprine pneumonia in relation to climatic factors in semiarid zone. Indian Journal of Small Ruminants 10 131-133.

Momin MA, Islam MA, Khatun MM, Rahman MM, Islam MA 2011: Characterization of bacteria associated with pneumonia in black Bengal goats. Bangladesh Journal of Veterinary Medicine 9 67-71.

Orós J, Fernández A, Rodríguez JL, Rodríguez F, Poveda JB 1997: Bacteria associated with enzootic pneumonia in goats. Zentralbl Veterinarmed 44 99-104.

Pinheiro RR, Gouveia AMG, Alves FSF, Haddad JPA 2000: Epidemiological aspects of goat production Ceara State, Brazil. Arquivo Brasileiro de Medicina Veterinária e Zootecnia 52 534-543.

Rimoldi GM, Moeller Jr RB 2013: Escherichia fergusonii associated with pneumonia in a beef cow. Journal of American Veterinary Medicine 31 361-364.

Tariq MA 1980: Studies on the incidence, epizootology and development of effective vaccines for the control of contagious caprine pleuropneumonia, contagious agalactia in sheep and goats in Balochistan. Annual Report, Livestock Department, Government of Balochistan, Quetta, Pakistan. 